\title{
Terms for 'Word' in Roman Grammar
}

\author{
Malcolm D. Hyman, Harvard University
}

\section{Introduction}

Let me start with an observation: there are numerous studies of the

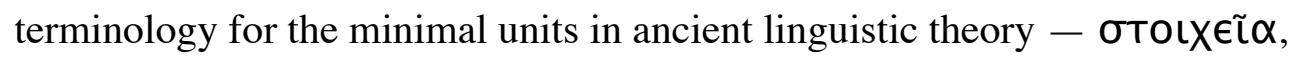

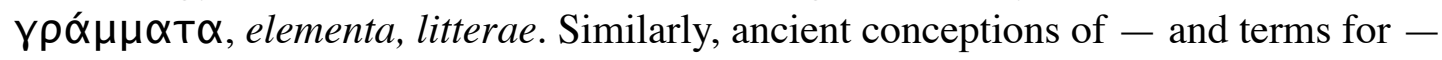
larger entities such as phrase, clause, and sentence have received considerable attention. Yet a systematic study of the terms Roman grammarians employ for word remains lacking. This fact seems all the more remarkable when we consider how crucial the word is to ancient grammar. The ancients generally regard the word as the minimal meaningful unit in language: thus words and word classes are called Toũ

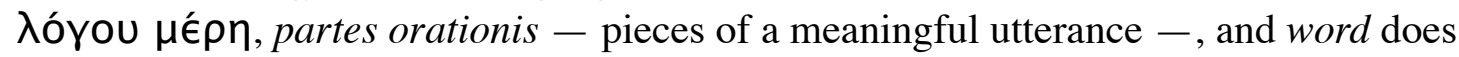
much of the work that the notion morpheme does in modern linguistics (cf. Matthews 2002: 269; but see Giannini 1989: 120-124). Varro defines verbum as "the smallest indivisible part of spoken language" (LL 10.77), and, as an eminent scholar has observed, Varro's theory "is [...] a word-based one" (Taylor 1974: 9). A typical ars grammatica begins with sections on vox, littera, and syllaba, but the bulk of the pages by far is occupied with discussion of word classes, inflectional and derivational morphology, word syntax, grammatical errors involving words, and rhetorical figures that are characterized by verbal alterations and substitutions.

We find in ancient grammatical texts quite a few terms for word; most of these have several distinct senses that are relevant to grammar. Quintilian notes that verbum is ambiguous - it has both a genus ('word') and a species ('verb') sense - and he remarks that some authors avoid the ambiguity by using vox, locutio, or dictio for the genus (1.5.2). In many texts we find an assortment of these terms - and others, for instance vocabulum. What distinctions are being made? What motivates the choice of one or more terms from a larger set of candidates? Some readers may find these questions uninteresting, because they regard the word as an intuitive and unproblematic concept. Yet on closer inspection "the concept 'word' is nothing if not elusive" (Packard 2000: 7). ${ }^{1}$ In this paper, I shall begin by discussing some conceptions of the word that have arisen in recent linguistic theory; in so doing, I introduce issues that will be central to my examination of the ancient terminology. The main part of the paper examines the relevant metalanguage in Roman grammar - with a particular focus on Varro, the grammatical chapters of Quintilian, and the Ars Maior of Donatus. I'll conclude with a few remarks on technical terminology and Fachsprache in general.

\section{Modern concepts of 'word' and wordhood}

The sociological word refers to "that type of unit, intermediate in size between

\footnotetext{
${ }^{1}$ Juilland \& Roceric (1972) provide a convenient annotated bibliography of linguistic studies concerned with the concept "word". For general orientation I recommend, in addition to the more recent works cited below, Rosetti( $\left.{ }^{2} 1947\right)$, Žirmunskij (1966), Lyons (1968: 194-206), and Krámský (1969).
} 
a phoneme and a sentence, which the general nonlinguistic public is conscious of, talks about, has an everyday term for, and is practically concerned with in various ways. It is the kind of thing which a child learns to say, which a teacher teaches children to read and write in school, which a writer is paid for so much per thousand [ ...] the kind of thing one makes slips of the tongue on, and for the right or wrong use of which one is praised or blamed" (Chao 1968: 136). The nature of such a unit can vary sharply from one speech community to another, influenced by such variables as language typology, orthographic norms, and historical tradition. ${ }^{2}$ Thus in Chinese the sociological word is the $z \grave{l}$ - which stands at once for a written character and a spoken monosyllabic morpheme - ; even though most words in Modern Standard Chinese are actually disyllabic (Packard 2000: 265-7). The zì dominates Chinese linguistic consciousness: publishers pay authors by the $z \grave{l}$, and speakers perceive sentences as sequences of zì (Read, Zhang, Nie \& Ding 1986; Ramsey ${ }^{2} 1989$ : 57-60).

The sociological word differs from those conceptions of the word that are advanced in the context of a formal linguistic theory. A given theory need not restrict itself to only one such conception: in fact, a significant amount of recent work employs differing notions of 'word' in separate domains. Thus we see reference to phonological words, morphological words, and syntactic words (Dai 1998). ${ }^{3}$ The phonological word is the domain over which so-called internal (as opposed to external) sandhi rules apply (Hall 1999). ${ }^{4}$ In Latin, for instance, nasal assimilation applies within the phonological word, so that iamdudum 'some time ago now' is realized phonetically as [jandu:dũ] ${ }^{5}$ (cf. IANDVDVM at CIL 10.476, 11.5750). Similarly, the Latin accent rule assigns stress to exactly one syllable of a phonological word (Cic. Orator 58; Quint. 1.5.27). The morphological word is the output of wordformation rules for a language; it is also the maximal domain for the application of morphological rules. Thus incipio 'I start, begin' is a morphological word created from in + capio. The syntactic word is the minimal unit to which syntactic rules may refer (i.e., it is a "syntactic atom"). In terms of X-bar theory, the syntactic word is $\mathrm{X}^{0}$ - it is at zero-bar-level (Di Sciullo \& Williams 1987: 78-80). ${ }^{6}$ (In French, *trompebien-l'oeil is impossible, because the insertion of bien 'well' violates the syntactic word trompe-l'oeil 'illusionistic painting'; cf. Lyons 1968: 202-204 on "uninterruptability".)

Sometimes the phonological, morphological, and syntactic word will be coextensive. Often, however, they will not. It is important to note the mismatches that may occur. (1) A content word together with one or more clitics may result in a phonological word that is not coextensive with a syntactic word. Thus virumque [wir ${ }^{\prime}$ un $\mathrm{k}^{\mathrm{W}} \epsilon$ ] (Virg. A. 1.1) is a single phonological word (with a single accent). Yet at the syntactic level, we see a noun and a conjunction. (2) Not all morphological words are syntactic words. Latin muscipulum 'mousetrap' is derived [[mus + capio $]+$

\footnotetext{
${ }^{2}$ For related discussions, see Tolchinsky Landsmann (2003: 184-200); Dixon \& Aikhenvald (2002a: 32-3).

${ }^{3}$ Some authors choose also to distinguish orthographic or graphic(al) words, that is, sequences of characters delimited by whitespace (cf. Haugen 2004: 84-5). In writing systems characterized by scriptura continua (e.g. many Latin manuscripts [cf. Bischoff 1990: 173], Medieval Nordic manuscripts, Modern Standard Chinese) the question of the orthographic word is more or less moot. At any rate, writing is a complex subject that lies beyond the scope of this paper.

${ }^{4}$ Cf. Dixon \& Aikhenvald (2002a: 13), who discuss additional criteria.

5 Or with a nasal off-glide finally, rather than the nasalized vowel (Nyman 1977).

${ }^{6}$ On the distinction between morphological and syntactic word: Dixon \& Aikhenvald (2002a: 6).
} 
ulum]. Yet ?muscipio 'catch mice' is unattested (i.e. does not function as a syntactic word), despite being a well-formed morphological word. (3) Certain items that might prima facie seem to be phrases must, in fact, be interpreted as syntactic words. One relevant principle here is that of Semantic Composition (Duanmu 1998): if the meaning of an expression cannot be determined by a combinatoric analysis of the meaning of its parts, then that expression is likely to be a word. Thus magister equitum means not 'master of horsemen' but rather 'second-in-command to the dictator'. It is a single syntactic word, although its constituents are both equally valid morphological and syntactic words. Similarly, res publica.

Another important set of word concepts has been widely elaborated in the psycholinguistic literature. One common view is that lexical access involves two distinct stages: the retrieval of semantic and syntactic information and the retrieval of phonological form (Roelofs, Meyer \& Levelt 1998). The object retrieved in the first stage is a lemma, a word's semantic and syntactic specification; the lemma, together with a set of diacritic variables (morphosemantic features such as grammatical number), allows the retrieval of a lexeme, the phonological representation of a word form, in the second stage. ${ }^{7}$ Natural language regularly confuses these senses; we say that canis and canit are both words, but also that they are forms of a single word. Clearly, however, the lemma concept was available to ancient grammarians; the

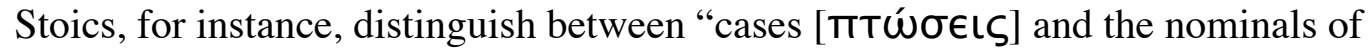
which they are cases" (Atherton 1993: 286-7 n. 60).

\section{Ancient terms for 'word'}

Now to the Romans. I'll begin with Varro:

quid enim similius potest videri indiligenti quam duo verba haec suis et suis? quae non sunt, quod alterum significat suere, alterum suem. itaque similia vocibus esse ac syllabis confitemur, dissimilia esse partibus orationis videmus, quod alterum habet tempora, alterum casus, quae duae res vel maxime discernunt analogias. ( $L L 10.7)$

For what can seem more alike, if one is not being careful, than the feminine nominal form suis ('of a sow') and the verb form suis ('you sg. sew')? But they are not: because the latter refers to sewing and the former to a sow. And so we agree that they are similar in sounds and syllables, but we see that they are dissimilar in parts of speech: because the latter has tenses, and the former has cases - and these two grammatical categories are the most important in determining analogies.

From this passage, we can gather several generalizations about Varro's usages generalizations that will, in fact, be borne out in continued reading of De Lingua Latina. First, verbum normally refers to a word form (such as musae, pedibus, pulsatis) - that is, a form that possesses the exponent(s) of certain morphosyntactic and morphosemantic categories. By vox (sometimes figura vocis) Varro refers to the

\footnotetext{
${ }^{7}$ N.B. that the terms are potentially confusing, in that some theories use lexeme in a sense approaching that here ascribed to lemma. For the reactions of morphologists, see Dixon \& Aikhenvald (2002a: 7).
} 
sound shape of a word - its phonological form. ${ }^{8}$ For Varro, it is word forms - rather than more abstract lemmata - that are primary. Thus, for nouns, what is imposed is the nominative (usually the NOM. SG.), and the remaining forms are given by inflectional morphology (declinatio naturalis), which is an automatic process: "sic in recto casu quas imponerent voces, ut illinc essent futurae quo declinarentur" ( $L L$ 8.7). ${ }^{9}$ Note that Varro characterizes imposition here as the assigning of sound sequences (voces). The vox, however is just the superficial aspect of a verbum, which Varro describes in terms of grammatical substance: morphosemantic features such as case and number he terms res. Morphology is a process that creates new word forms by manipulating a word's phonological shape ("vocis commutatio fit aliqua," $L L$ 10.77).

Varro also employs the term vocabulum, which is polysemous in the same way as verbum: both can be used generically to mean 'word', but verbum specifically denotes 'verb'; and vocabulum, 'common noun' (“de nominibus, quae differunt a vocabulis ideo quod [...] significant res proprias," LL 8.80; cf. 10.19). ${ }^{10}$ When Varro speaks of the imposition (impositio, imponere) of words, he most commonly calls the assigned words vocabula or nomina (e.g. "voluntatem dico impositionem vocabulorum," 10.51). Only once in Book 10 does he use verbum of what is imposed, and he does so in the context of a parallel construction where the lexical choice is at least as likely to have been made to fit the second verb (declinantur) as the first (imponuntur): "et in his verbis quae imponuntur et in his quae declinantur" (10.35). Why this preference for vocabulum rather than verbum to refer to what is imposed? Perhaps Varro has a picture of language in mind similar to that Augustine develops at Confessions 1.8 (where he describes his acquiring language as a child): in other words, names for things constitute the paradigmatic instance of newly created words (just as, in the Confessions passage, they are the primary words learned).

Varro also employs vocabulum in the sense 'term' - thus at 10.6 he states that a particular controversy is more a matter of terminology (vocabulum) than of fact or substance (res) ("fit ut potius de vocabulo quam de re controversia esse videatur").

On to Quintilian. Although the author of the Institutio observes that others use terms such as dictio and locutio, he himself eschews them. The term dictio in the sense "word" is used only in the definition of tropus at 9.1.4, locutio never. When he writes vocabulum, he uses it in the sense 'common noun' (i.e. as an equivalent of тробпүорі́ $\alpha$ : 1.4.20-1, 1.5.45); unlike Varro, he generally doesn't use it as a term for 'word'. ${ }^{11}$ The basic term for word in Quintilian is verbum. Frequently it occurs in the expressions singulum verbum and plura verba, which constitute two principle divisions of grammar: "haec [sc. emendate loquendi regula] exigitur verbis aut

\footnotetext{
${ }^{8}$ Cf. Taylor (1974: 120): “vox: [...] The surface phonological representation of a word.” Menge ('1977: §297): “vox: 'Wort', nach Aussprache und Klang, jeder mit der Stimme hervorgebrachte Laut oder Ton."

${ }^{9}$ At LL 10.82 Varro uses vocabuli series for a nominal paradigm such as caput capiti capitis capite. Although vocabulum might refer here to the entire set of forms, Varro instead could mean that the oblique forms issue from caput - just as he states at 8.4 that Aemilii, Aemilium, etc. are in a line of descent (eiusdem stirpis) from the nominative Aemilius. (The adjective singularis may be understood as modifying either vocabuli or series.)

${ }^{10}$ Sometimes Varro uses vocabulum for 'noun, nominal', including both common and proper subtypes (e.g. $L L 8.11$ ).

11 Never in the grammatical chapters. But see 1.1.34, 9.1.7. 
singulis aut pluribus" (1.5.2). ${ }^{12}$

In addition to using verbum to mean 'word', Quintilian also uses it to refer to the constituents of a morphological word, irrespective of whether they constitute valid independent word forms. Word forms may be simple (simplices voces) or compound (compositae voces) (1.5.65). Quintilian recognizes two types of compounds: those formed from preverb + word (e.g. innocens) and those formed from word + word. Here word may be a valid independent word form in the language (verbum integrum) or not (verbum corruptum). Quintilian recognizes that the four possible permutations all exist (1.5.68): ${ }^{13}$

\begin{tabular}{|l|l|l|}
\hline TYPE & EXAMPLE & \\
\hline integrum + integrum & superfui 'I remained alive' & $<$ super + fui \\
\hline integrum + corruptum & malevolus 'malevolent' & $<$ male $+{ }^{*}$ volus \\
\hline corruptum + integrum & noctivagus 'night-roaming' & $<*$ nocti + vagus \\
\hline corruptum + corruptum & pedisecus 'manservant' & $<*$ pedi $+{ }^{*}$ secus \\
\hline
\end{tabular}

Thus Quintilian poses the question:

quid quod quaedam, quae singula procul dubio vitiosa sunt, iuncta sine reprehensione dicuntur? nam et 'dua' et 'tre' diversorum generum sunt barbarismi, at 'dua pondo' et 'tre pondo' usque ad nostram aetatem ab omnibus dictum est. (1.5.15)

Why is it that words which are without a doubt wrong in isolation are deemed unobjectionable when combined? For $d u a$ and tre both are various kinds of barbarism, but duapondo 'two pounds in weight' and trepondo 'three pounds in weight' have been spoken by everyone all the way down to our own era.

The other important term for a word concept in Quintilian is vox. We have seen that for Varro vox means 'the phonological representation of a word'. A characteristic use of vox for Quintilian is to mean 'word form considered in its phonological aspect (with no implication of meaningfulness) '. ${ }^{14}$ It's easy to understand how this usage develops: one of the fundamental meanings of vox in Latin is 'vocalization', which (like Greek $\varphi \omega v \eta ́$ ) might refer to a word, but also a cry of pain, or the yelp of an animal. ${ }^{15}$ Thus Quintilian criticizes Varro's etymology of gragulus 'jackdaw' $(<$ gregatim 'in flocks', because jackdaws fly in flocks); rather, Quintilian states (correctly, as it happens), it's obvious (manifestum) that the word is derived from the cries of the jackdaws themselves ("ex vocibus avium," 1.6.37). Hence usages such as

\footnotetext{
12 Compare the structure of the LL: "Les deux prèmieres parties du De lingua Latina correspondaient aux prèmieres subdivisions de l'étude du mot considéré en lui-même [...] et la troisième partie correspondait d'une part à la dernière de ces subdivisions (ordinatio), et d'autre part à toute l'étude relative aux problèmes posés par l'énoncé" (Baratin 1989: 225-6).

13 Cf. Donatus Mai. 637.8-9 Holtz.

14 Biese (1954: 12) attributes to Quintilian the senses verbum = "“Wort' mit Bezug auf die Bedeutung" and vox = "Einzelwort (auch mit Bezug auf seine Lautgestalt)." These are largely correct, although they will not be applicable to each and every occurrence of verbum or vox in Quintilian.

15 For Aristotle, those animals have $\varphi \omega v n ́$ that possess lungs and a windpipe (De anima II 8 420b29-421a). See Zirin (1980: 334-5) and Ax (1986: 119-38).
} 
the following:

id quoque inter prima rudimenta non inutile demonstrare, quot quaeque verba modis intellegenda sint. circa glossemata etiam, id est voces minus usitatas, non ultima eius professionis diligentia est. (1.8.15)

In the elementary stage of education, it is not without use to demonstrate in how many ways certain words may be understood. In the area of glosses, i.e. less frequently used words, the grammarian must also exercise due diligence.

Quintilian is speaking of words' meanings, but when he comes to glossemata difficult and unusual words that will require interpretation - he describes them as they will seem at first to students: as voces, mere vocalizations, bereft of meaning. ${ }^{16}$

Quintilian not infrequently uses vox in the context of what we would today call the "phonological word." Thus he indicates that Latin prepositions are rightleaning clitics:

nam cum dico 'circum litora', tamquam unum enuntio dissimulata distinctione, itaque tamquam in una voce una est acuta. (1.5.27)

For when I say circum litora 'round the seashore', I pronounce it as a single unit, with the word-division concealed, so that there is a single acute accent, as in a single word.

The Latin accent rule applies over the domain of the phonological word. Here is Quintilian's statement of the rule:

est autem in omni voce utique acuta, sed numquam plus una nec umquam ultima, ideoque in disyllabis prior. praeterea numquam in eadem flexa et acuta, quia in flexa est acuta; itaque neutra cludet vocem Latinam. (1.5.31)

In every (phonological) word there is a single acute accent, but never more than one, and never on the final syllable (thus in disyllables, the initial syllable is always accented). Furthermore, a single word never contains both a circumflex accent and an acute, since the circumflex accent itself includes an acute. And neither acute nor circumflex can appear on the final syllable of a Latin (phonological) word.

Quintilian's metalanguage, however, is still rather inchoate. At times the choice of terms such as verbum or vox seems motivated by more rhetorical than scientific concerns. Consider this passage, on the question of single-word solecisms:

illud eruditius quaeritur, an in singulis quoque verbis possit fieri soloecismus. [...] in gestu etiam nonnulli putant idem vitium inesse, cum aliud voce, aliud nutu vel manu demonstratur. huic opinioni neque omnino accedo neque plane dissentio; nam id fateor accidere voce una, non tamen

\footnotetext{
16 That is, of course, a matter of connotation - not denotation.
} 
aliter quam si sit aliquid, quod vim alterius vocis optineat, ad quod vox illa referatur: ut soloecismus ex complexu fiat eorum quibus res significantur et voluntas ostenditur. atque ut omnem effugiam cavillationem, sit aliquando in uno verbo, numquam in solo verbo. $(1.5 .36-7)$

A more learned question is whether solecism can also occur in single words. [...] Some people even suppose that the same mistake can occur in a gesture, when the voice says one thing, but the hand or the nod of the head says another. Neither do I fully agree with this opinion, nor do I fully reject it. For I say that it happens in a single word only if there is something else that has the semantic value of a second word, to which the aforementioned word may be referred - so that solecism occurs in the combination of those tokens by which referents are signified and our meaning is indicated. And that I may escape all quibbling, let's say: sometimes in a single word, but never in a word all by itself.

Quintilian begins with the "default," less marked term for "word' (verbum). The first occurrence of vox doesn't mean word at all, but rather 'vocal channel of communication' as opposed to 'gestural channel'. But, because the term aids the argument that nonverbal (or nonvocal) tokens can serve a communicative function equivalent to that of words, he uses forms of vox for 'word' three times in a single sentence. Finally, for the pithy sententia that concludes the paragraph, he returns to the term with which he originally phrased the question (verbum).

When we come to the late antique artes grammaticae, we find that some terminological developments have taken place. Two stand out in particular. First, the term dictio for 'word' has gained in popularity. Second, pars orationis is used not only to mean 'word class' but also '(single) word token'. We know from Quintilian that earlier authors used dictio for 'word', but we don't know who they were. (Remmius Palaemon always lurks in the shadows.) We might suppose that the shift was motivated by a desire to avoid the ambiguity of verbum ('word' or 'verb'), vocabulum ('word' or 'common noun' or 'nominal'), and vox ('word' or 'spoken sound'). But if this was the motivation, the shift wasn't very helpful, since, as Cominianus (apud Charisium) notes, dictio is also ambiguous:

barbarismus est dictio vitiosa. haec autem definitio et generalis est et specialis. sed quoniam dictio et contexta oratio et una pars eius intellegitur, consuetudo hunc tantum barbarismum appellat qui fit in una parte orationis. (349.18-23 Barwick)

Barbarism is a defective locution. This definition, however, is both general and specific. But since "locution" (dictio) means both "connected speech' and 'a single part of connected speech', it's customary to use the term barbarism only in the case of a single part (i.e. a word, pars orationis).

Why then dictio? For one thing, it suggests the influence of Greek grammar: the term corresponds morpheme-by-morpheme to Greek $\lambda \dot{\epsilon} \xi \iota \varsigma$ (Holtz 1981: 139; Matthews 2002: 267-8; Dinneen 1985: 158). We must admit, however, that it's not a very good equivalent for $\lambda \epsilon \in \xi ı \zeta$ : for one thing, its natural-language equivalents ('act of 
speaking', 'utterance', 'speech') get in the way - as we've just seen Cominianus note (cf. Menge ${ }^{6} 1977:$ §209). Also, when Roman grammarians use dictio for '(meaningful) word', they are fundamentally at odds with the Stoics, for whom $\lambda \hat{\epsilon} \xi \iota \varsigma$ was a 'possible (but not necessarily meaningful) sound sequence' (Collinge 1986: 12).

When Donatus uses dictio, he most often means 'word form'. Thus, in discussing phonology (e.g. "acutus cum in Graecis dictionibus tria loca teneat," Mai. $609.6 \mathrm{Holtz}) ;{ }^{17}$ in asserting that certain phonetically (and graphically) identical forms may be ascribed to more than one word class (e.g. "sunt multae dictiones dubiae inter adverbium et nomen, ut 'falso'," 643.4 - verbum would be awkward here, as it designates a single word class; likewise pars orationis, which is the vox propria for 'word class' in general); and in defining figures and the like ${ }^{18}$ (e.g. "syncope est ablatio de media dictione contraria epenthesi," 661.7). We see other meanings for dictio: in a few definitions, it seems to mean 'lemma' - thus "acyrologia est inpropria dictio" (658.8; e.g. sperare 'hope' for timere 'fear'; cf. p. 667.2-3 Holtz). (No matter what form of sperare I use when I should have used a form of timere, I

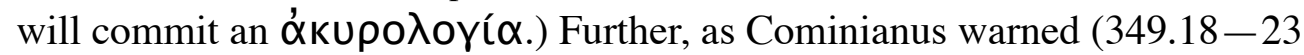
Barwick, quoted above), dictio may refer to a syntagmatic group:

cacemphaton est obscena enuntiatio vel in composita dictione vel in uno verbo. $(658.11)$

Cacemphaton is an obscene expression, either in a compound locution or in a single word.

Or:

polysyndeton est multis nexa coniunctionibus dictio. (666.11)

Polysyndeton is a locution connected with many conjunctions.

Finally, there is a lone instance in which dictio seems to mean something like 'paradigmatic group of words':

tautologia est eiusdem dictionis repetitio vitiosa, ut 'egomet ipse.' (659.5)

Tautology is the faulty repetition of the same locution, e.g. egomet ipse.

This would seem to be a strange use of dictio indeed. Neither can it mean 'single word' (egomet and ipse are decidedly different words), nor can dictio mean 'phrase' in dictionis repetitio. Donatus's definition of tautology strikes one as quite inept; here, much better, is that of Charisius:

tautologia est eiusdem vel idem significantis verbi iteratio, ut 'egomet ipse.' (357.17-8 Barwick)

\footnotetext{
${ }^{17}$ All further references to Donatus's Ars Maior are to the edition of Holtz (1981).

${ }^{18}$ Mai.: acyrologia, eclipsis, cacosyntheton, amphibolia, prosthesis, epenthesis, paragoge, aphaeresis, syncope, apocope, homoeoteleuton, tropus, metalempsis, hyperbole.
} 
Tautology is the repetition of the same word or of a word that means the same, e.g. egomet ipse.

Donatus uses pars orationis in several senses:

1. 'word class', what we are used to calling "part of speech"; this is the characteristic usage and requires no further comment. ${ }^{19}$

2. 'lexical item belonging to a particular word class': the token-of-a-type sense, to be distinguished from the pure typal sense. Thus when Donatus writes, "per partes orationis fiunt soloecismi" (655.17), he means that solecisms may arise from using the wrong noun, pronoun, adverb, etc. - e.g. using a feminine adjective when a masculine is demanded.

3. simply 'word', where the word class is irrelevant (thus synonymous with dictio), e.g. "cum pars orationis desinit in longam" (606.12) — "when a word ends in a long syllable." 20

In one passage, Donatus uses pars orationis to refer to the applicability of the Latin accent rule to a complex phonological word, such as ab usque or de hinc. These, he writes, are pronounced as a single phonological word, and thus are assigned a single stress accent ("sed haec tamquam unam partem orationis sub uno accentu pronuntiabimus," 643.14-5).

Donatus uses one other term, verbum, for 'word'. Very frequently he uses it in the specific sense 'verb' (see esp. the section De Verbo, 632.5-39.12); relatively often, however, it means simply 'word'. Thus e.g. "homoeoptoton est, cum in similes casus exeunt verba diversa" (665.14). Homoeoptoton is the name of a rhetorical device where a series of different words have phonetically similar case endings. That such words must be nominals (for only nominals possess case) demonstrates that for Donatus verbum may be completely bleached of its association with verbs.

The following passage provides us an excellent opportunity to compare the way in which Donatus uses three different terms for 'word':

in compositis dictionibus unus accentus est non minus quam in una parte orationis, ut malesanus, interealoci. accentus in integris dictionibus observantur, in interiectionibus et in perigrinis verbis et in barbaris nominibus nulli certi sunt. $(610.8-10)$

In compound words there is a single accent just as there is in a single "part of speech" (e.g. malesánus, intereáloci). Accents are maintained in valid word forms; but in interjections, foreign words, and barbarians' names, they are never certain.

Donatus's NP compositae dictiones is akin to Quintilian's compositae voces (1.5.65). Like Quintilian, Donatus seems motivated to use a different term for the output of the word formation rule (dictio for D., vox for Q.) than for its inputs (partes orationis for

\footnotetext{
${ }^{19}$ See $613.3,4,6 ; 614.2 ; 629.2 ; 632.5 ; 637.8 ; 640.2,4 ; 644.2,648.4$ (bis); 652.5, 10; 656.6 .

${ }^{20}$ See 606.11; 653.2 (here cf. Holtz [1981: 140]); 655.4, 8. 
D., verbum for Q.). Note that dictio is associated with morphology (word-formation rules), whereas pars orationis is associated with syntax (it is basically a constituent at the syntactic level). Donatus remarks that the Latin accent rule applies to well-formed dictiones; for certain problematic linguistic items, however, it is questionable. These include interjections, which pose significant difficulties for the grammarians (Sluiter 1990: 173-245); foreign words (I take verbis as standing here for verbs, common nouns, etc.), and barbarian names (personal names, toponyms, ethnic names ...).

There are two terms - which we have already examined in earlier authors that Donatus doesn't use generically to mean 'word'. These are vocabulum and vox. For Donatus, vocabula denote inanimate things in contradistinction to proper personal names (nomina) and names for groups of people (appellationes) (614.4-5; contrast Quintilian 1.4.21). There is also at least one occasion in the Ars Maior where vocabulum means something like correct term:

catachresis est usurpatio nominis alieni, ut 'parricidam' dicimus qui occiderit fratrem, et 'piscinam' quae pisces non habet. haec nisi extrinsecus sumerent, suum vocabulum non haberent. (668.8-10)

Catachresis is the appropriation of the name for something else (e.g. we call someone who's murdered his brother a parricide 'father-murderer'; 21 or we call a pool that doesn't contain fish piscina 'fish pool'). If these concepts didn't adopt a name from something else, they wouldn't have a term of their own.

Donatus's use of vox is very interesting. He uses it, of course, as a technical term in the De Voce chapter of his Ars (603.1-4). ${ }^{22}$ Otherwise, he uses it only twice - both times in the context of the theory of the interjection. First the definition:

interiectio est pars orationis interiecta aliis partibus orationis ad exprimendos animi adfectus [...] sed haec apud Graecos adverbiis adplicantur, quod ideo Latini non faciunt, quia huiusce modi voces non statim subsequitur verbum. (652.5-9)

An interjection is a part of speech interjected between other parts of speech for the purpose of expressing mental states (emotions). [...] The Greeks attach interjections to the class of adverbs. Romans don't do that, because vocalizations of this sort are not in immediate construction with a verb.

Further:

accentus in interiectionibus certi esse non possunt, ut fere in aliis vocibus, quas inconditas invenimus. (652.12-13)

\footnotetext{
${ }^{21}$ The ancients derive parricida from pater — thus 'father-killer'; in fact, the word is related to Greek тா彳ós 'kinsman'.

${ }^{22}$ That is, in the chapter that treats the fundamental acoustic material of language (Latin vox, Greek $\varphi \omega v n$ ). Here see the essential study of Ax (1986).
} 
Stress accents in interjections can't be reliable, nor for the most part are accents in other expressions which we consider to be "disordered sounds." 23

When Donatus uses vox here, he uses it as part of the special technical vocabulary of the Roman grammarians relating to the interjection (vox incondita etc.). Interjections are more quasi-linguistic than genuinely linguistic; hence the use of vox, which Donatus otherwise doesn't use for 'word'. Interjections are abnormal from the point of phonology (e.g. they may end in /h/ - ah! vah! - which is normally prohibited in Latin: Priscian GL 2.19.26-20.8) They are also characteristically difficult to decompose morphologically and are in some sense "tangential" to syntax. (If we consider the pain language of Philoctetes in Sophocles' play, it is neither genuinely

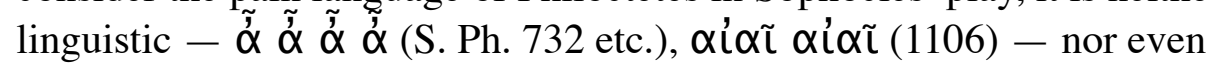
characteristically human; cf. Scarry 1985: 5)

When we get to Priscian, we find a considerably more developed metalanguage. Here dictio has really become a technical term for 'word' and is given a definition that clarifies its identity at both syntactic and semantic levels:

dictio est pars minima orationis constructae, id est in ordine compositae: pars autem quantum ad totum intellegendum, id est ad totius sensus intellectum; hoc autem ideo dictum est, ne quis conetur 'vīrēs' in duas partes dividere, hoc est in ' $\mathrm{v} \overline{1}$ ' et 'rēs', vel quaedam huiuscemodi. non enim ad totum intellegendum haec fit divisio. ( $G L$ 1.53.14 ff.)

A word is the smallest part of connected speech, i.e. of speech in syntactic construction - moreover, a part that is semantically complete, in other words, that leads to an understanding of the entire meaning. This proviso has been added lest anybody try to divide $v \bar{t} r \bar{e} s$ into two parts (i.e. $v \bar{l}$ and $r \bar{e} s$ ), or anything like that. For this division doesn't give the sense of the whole.

Here dictio is carefully positioned within the linguistic hierarchy littera-syllaba-dictio-oratio (Priscian GL 3.110.10-1). It is the unit that is combined into meaningful utterances, but at the same time it is distinguished from the next smallest unit, the syllable. Thus, although vires may be divided into the syllables $v i$ and res (both of which are potential word forms in Latin), it cannot be said to be composed of these two words, since the semantic analysis presupposed by that definition is unsatisfactory.

Priscian does, however, acknowledge that a lexical item (dictio) with complex internal structure may be realized discontinuously:

sed etiam dictio dividitur, ut si dicam 'res publica felix est' et 'res felix est publica'; 'magister militum fortis', 'militum fortis magister'. ( $G L$ 3.113.6-7)

\footnotetext{
${ }^{23}$ For this translation of vox incondita, see Sluiter (1990: 193 n. 76). Cf. Donatus Min. 602.2: "interiectio quid est? pars orationis significans mentis affectum voce incondita."
} 
But even a word may be realized discontinuously: e.g. I may say res publica felix est ("the state is prosperous") or res felix est publica; magister militum fortis ("brave commander of the unit") or militum fortis magister.

Likewise, such a complex form is liable to metathesis or transmutatio; e.g. tribunus plebis 'tribune of the plebs' may be realized as plebis tribunus (GL 2.114.3-4).

Finally, something should be said about the term locutio, which Quintilian mentioned. This term is actually quite rare in the grammarians, although Charisius uses it to define dictio, his basic term for 'word':

dictio est ex syllabis finita cum significatione certa locutio, ut est 'dico' 'facio'. (14.26-7 Barwick)

A word is a complete locution composed of syllables and with a determined meaning, e.g. dico 'I speak', facio 'I do'.

The term also occurs in the appendix of differentiae 'verbal distinctions':

barbaram locutionem et barbarismon. barbara locutio proprie peregrina est, barbarismos fit etiam in latini sermonis locutione. (397.3-5 Barwick)

[The distinction between] barbara locutio and barbarismos: barbara locutio is properly speaking a foreign word, while barbarismos can occur even in a word of the Latin language.

The source for this differentia is traditionally thought to be Cornelius Fronto (ca. 100-176 C.E.); thus it belongs to a period for which we have few examples of grammatical terminology. It would seem that locutio here is an attempt to Latinize $\lambda \epsilon \in \xi \iota \zeta$; the phenomenon described is more frequently termed barbarolexis (i.e. $\beta \alpha ́ \rho \beta \alpha \rho \circ \varsigma \lambda \epsilon \in \xi \iota \zeta)$ in the later artes grammaticae (Vainio 1994).

\section{Conclusion}

A few concluding remarks are in order. Taylor (1996: 55) has written that "Varro's metalanguage is neither fixed nor formulaic, for the language of science has not yet established itself as an entity different from that of normal intellectual discourse; his usage is remarkably consistent, however." That is to say, an author such as Varro exploits the nuance and potential for nuance of the everyday vocabulary at his disposal. With the development of the ars grammatica - as hinted at by Quintilian and exemplified from the third century on - a technical language with somewhat different characteristics begins to emerge. That dictio - with its abstract nominalizing suffix and apparent relation to an item of Greek grammatical jargon gains popularity demonstrates the pressure on authors to establish a technical lexicon that avoids some of the difficulties of ordinary language. They don't end up with a single unambiguous and univocal term for 'word', but their metalanguage is sufficiently developed that they can successfully communicate some precise 
distinctions. ${ }^{24}$

${ }^{24}$ Thanks go out to: Thorsten Fögen, Christoph Harbsmeier, Robert Moore, Mark Schiefsky, Dan Taylor, Philip Thibodeau, and Alfons Wouters. The Max-Planck-Institut für Wissenschaftsgeschichte in Berlin has generously provided me with a comfortable place to work. 


\section{Bibliography}

Atherton, Catherine. (1993): The Stoics on Ambiguity, Cambridge.

Ax, Wolfram. (1986): Laut, Stimme, und Sprache: Studien zu drei Grundbegriffen der antiken Sprachtheorie, Hypomnemata 84, Göttingen.

Baratin, Marc. (1989): La naissance de la syntaxe à Rome, Paris.

Barwick, Karl. (Ed.) (1964): Flavii Sosipatri Charisii Artis Grammaticae Libri V, Leipzig. [revisededition by Friedmar Kühnert, 1964; repr. Stuttgart \& Leipzig 1997]

Biese, Y.M. (1954): “Zwei Beiträge zur Geschichte der Römischen Grammatik. 1. Zu Quint. Inst. X 1.11; 2. Bemerkungen zu einigen Grammatikerstellen über die Interjektionen", in: Arctos, 1 (n.s.), 9-15.

Bischoff, Bernhard. (1990): Latin Palaeography: Antiquity \& the Middle Ages, trans. Dáibhí Ó Cróinín \& David Ganz, Cambridge.

Chao, Yuen Ren. (1968): A Grammar of Spoken Chinese, Berkeley.

Collinge, N.E. (1986): "Greek (and Some Roman) Preferences in Language Categories", in: Theodora Bynon \& Frank Palmer (Edd.), Studies in the History of Western Linguistics (In Honour of R.H. Robins), Cambridge, 11-21.

Dai, John Xiang-Ling. (1998): "Syntactic, Phonological, and Morphological Words in Chinese", in: Packard (1998), 103-34.

Di Sciullo, Anna-Maria \& Edwin Williams. (1987): On the Definition of Word, Linguistic Inquiry Monographs, Cambridge, Mass.

Dinneen, Francis P. (1985): “On Stoic Grammatical Theory”, in: Historiographia Linguistica, 12, 149-64.

Dixon, Robert M.W. \& Alexandra Y. Aikhenvald. (2002a): "Word: A Typological Framework", in: Divon \& Aikhenvald (2000b), 1-41.

Dixon, Robert M.W. \& Alexandra Y. Aikhenvald (Edd.) (2002b): Word: A CrossLinguistic Typology, Cambridge.

Duanmu, San. (1998): “Wordhood in Chinese,” in: Packard (1998), 135-96.

Giannini, Stefania. (1989): "Ratio e natura nei grammatici latini: indizi per la ricostruzione dei criteri di analisi fonologica e morfologica", in: Studi e Saggi Linguistici, 29, 107-49.

Hall, Tracy A. (1999): “The Phonological Word: A Review,” in: Tracy A. Hall \& Ursula Kleinhenz (Edd.), Studies on the Phonological Word, Current Studies in Linguistic Theory 174, Amsterdam, 1-22.

Haugen, Odd Einar. (2004): "Parallel Views: Multi-level Encoding of Medieval Nordic Primary Sources”, in: Literary \& Linguistic Computing, 19, 73-91.

Holtz, Louis. (1981): Donat et la tradition de l'enseignement grammatical: étude sur l'Ars Donati et sa diffusion $\left(I V^{e}-I X^{e}\right)$ et édition critique, Paris.

Juilland, Alphonse G. \& Alexandru Roceric. (1972): The Linguistic Concept of Word: 
Analytic Bibliography, The Hague.

Krámský, Jiři. (1969): The Word as a Linguistic Unit, The Hague.

Lyons, John. (1968): Introduction to Theoretical Linguistics, Cambridge.

Matthews, Peter H. (2002): "What Can We Conclude?", in: Dixon \& Aikhenvald (2002b), 266-81.

Menge, Herrmann. ( $\left.{ }^{6} 1977\right)$ : Lateinische Synonymik, Heidelberg.

Nyman, M. (1977): “Mytacism in Latin Phonology”, in: Glotta, 55, 111-20.

Packard, Jerome L. (2000): The Morphology of Chinese: A Linguistic and Cognitive Approach, Cambridge.

Packard, J.L. (Ed.) (1998): New Approaches to Chinese Word Formation: Morphology, Phonology and the Lexicon in Modern and Ancient Chinese, Berlin.

Ramsey, S. Robert. ( $\left.{ }^{2} 1989\right):$ The Languages of China, Princeton.

Read, Charles A., Yun-Fei Zhang, Hong-Yin Nie \& Bao-Qing Ding (1986): “The Ability to Manipulate Speech Sounds Depends on Knowing Alphabetic Writing", in: Cognition, 24, 31-44.

Roelofs, Ardi, Antje S. Meyer \& Willem J.M. Levelt (1998): “A Case for the Lemma/ Lexeme Distinction in Models of Speaking: Comment on Caramazza and Miozzo (1997)", in: Cognition, 69, 219-30.

Rosetti, Alexandru. (21947): Le mot: esquisse d'une theorie générale, Copenhagen.

Scarry, Elaine. (1985): The Body in Pain, New York.

Sluiter, Ineke. (1990): Ancient Grammar in Context: Contributions to the Study of Ancient Linguistic Thought, Amsterdam.

Taylor, Daniel J. (1974): Declinatio: A Study of the Linguistic Theory of Marcus Terentius Varro, Studies in the History of the Language Sciences 2, Amsterdam.

Taylor, Daniel J. (Ed.) (1996): Varro De Lingua Latina X: A New Critical Text and English Translation with Prolegomena and Commentary, Studies in the History of the Language Sciences 85, Amsterdam.

Tolchinsky Landsmann, Liliana. (2003): The Cradle of Culture and What Children Know About Writing and Numbers Before Being Taught, Developing Mind Series, Mahwah, N.J.

Vainio, Raija. (1994): "On the Concept of Barbarolexis in the Roman Grammarians", in: Arctos, 28 (n.s.), 129-40.

Zirin, Ronald A. (1980): “Aristotle's Biology of Language”, in: Transactions of the American Philological Association, 110, 325-47.

Žirmunskij, Viktor M. (1996): “The Word and its Boundaries”, in: Linguistics 27, 65-91. 